\title{
Characterization of cell response in Chlamydomonas moewusiicultures exposed to the herbicide paraquat: Induction of chlorosis
}

Raquel Prado, Carmen Rioboo, Concepción Herrero, Ángeles Cid,1

Aquatic Toxicology Volume 102, Issues 1-2, March 2011, Pages 10-17

Received 6 September 2010, Revised 15 December 2010, Accepted 22 December 2010,

Available online 28 December 2010

DOI: 10.1016/j.aquatox.2010.12.013

\begin{abstract}
The use of herbicides constitutes the principal method of weed control, but the introduction of these compounds into the aquatic environment can provoke severe consequences for nontarget organisms such as microalgae. Effects of the widely used herbicide paraquat were assessed on the green freshwater microalga Chlamydomonas moewusiiby means of the analysis of its photosynthetic pigment content, using a traditional spectrophotometric technique that provides population bulk measurements, and by means of flow cytometry, which allowed characterizing the microalgal response at a single-cell level. Results obtained reveal that paraquat concentrations above $50 \mathrm{nM}$ induce chlorosis in a percentage of microalgal cells depending on herbicide concentration and exposure time, as reflected by a reduced cell chlorophyll autofluorescence and pigment content of the biomass. Cell viability in these cultures was also reduced in a concentration dependent way. The possibility of analysing chlorotic and non-chlorotic subpopulations separately allowed the study of morphological properties and physiological status of both cell types, leading to the conclusion that chlorotic cells are nonviable cells, based on their reduced size and complexity and their inability to be stained in the fluorescein diacetate assay. In the case of non-chlorotic cells, cell viability was reduced with the increase of paraquat concentration. Non-chlorotic cells in these cultures showed an increased size and complexity in comparison with control cells, probably due to a growth inhibition. Chlorophyll fluorescence was the most sensitive parameter since even cells exposed to the lowest concentration assayed, $50 \mathrm{nM}$, although not chlorotic, showed a significantly reduced chlorophyll fluorescence with respect to control cells, reflected also by a reduced chlorophyll content of the biomass.
\end{abstract}

\section{Abbreviations}

- a.u., arbitrary units;

- FS, forward light scatter;

\footnotetext{
${ }^{1}$ Laboratorio de Microbiología, Facultad de Ciencias, Universidad de A Coruña, Campus de A Zapateira s/n, 15008 A Coruña, Spain
} 
- SS, side light scatter;

- FL, fluorescence;

- PI, propidium iodide;

- FDA, fluorescein diacetate

\section{Keywords}

Paraquat; Chlamydomonas; Flow cytometry; Chlorophyll fluorescence; Chlorosis; Viability

\section{Introduction}

Aquatic environments are often contaminated with numerous organic and inorganic compounds, including herbicides which are among the most widely used toxic chemicals for various purposes in industry, forestry, agriculture and households (Bi Fai et al., 2007 and Fatima et al., 2007). Many herbicides have high water solubility and low sorption coefficients, allowing rapid uptake into target plants. Such physicochemical properties, however, also render them susceptible to off-site transfer into the aquatic environment, increasing the risk for exposure of non-target organisms such as microalgae (Deneer, 2000 and Warren et al., 2003). As a result, herbicides have become some of the most frequently occurring organic pollutants in aquatic ecosystems all over the world, and it is essential to assess the effects of these compounds on non-target microalgal species, since microalgae, as primary producers, are of initial importance in providing the energy that sustains invertebrates and fish in these ecosystems and the effects of toxic substances on them are therefore important not only for the organisms themselves, but also for the other organisms in the food chain (Daam et al., 2009, De Lorenzo et al., 2002 and Rioboo et al., 2007).

Furthermore, the development and application of methods for the detection of contaminants based on the physiological response of organisms have become a high priority objective with the purpose of providing an early warning of sublethal pollution (Eullaffroy and Vernet, 2003). Algal growth measurements are the most frequently used methods of herbicide toxicity assessment (Nalewajko and Olaveson, 1998 and van Wezel and van Vlaardingen, 2004), and pigment content has also been used as biomarker of exposure to herbicides in plants including algae (Couderchet and Vernet, 2003). These endpoints are evaluated by means of traditional techniques which provide bulk measurements and do not allow us to observe possible intercellular differences within the cellular population analysed. In that respect, flow cytometry has been introduced as an alternative to these more traditional techniques for studying the response of microalgal cells exposed to different pollutants in toxicity bioassays (Franqueira et al., 2000). This technique allows us to perform quantitative measurements of individual cells in large numbers and in appreciably short time (Jochem, 2000), making it possible to distinguish subpopulations of cells that respond differently to the toxic agent.

Paraquat (1-1' dimethyl 4-4' bipyridylium dichloride), a non-selective, contact, broad-spectrum herbicide, is widely used around the world to prevent growth of broadleaf weeds and grasses on 
railways and roadsides, reaching the aquatic environment by runoff or leaching (Ibáñez et al., 1996). This compound exerts its toxic effects through the generation of free oxygen radicals (Ananieva et al., 2004 and Suntres, 2002). Paraquat replaces the ferredoxin in photosystem I, preventing electron transport to NADP, and becomes a reduced monocation radical that reacts with oxygen, yielding superoxide anion, which in turn can lead to the formation of hydrogen peroxide and hydroxyl radicals. In this way, phytotoxicity would arise not only through NADPH depletion, but also via generation of highly toxic reactive oxygen species (Eullaffroy and Vernet, 2003). This herbicide can be toxic for a wide variety of non-target species of primary producers, such as microalgae. However, its potential adverse effects on these organisms have been poorly studied and only very limited numbers of studies have reported on the effects of this herbicide on parameters other than growth or biomass (Franqueira et al., 1999, Jamers and De Coen, 2010, Prado et al., 2008 and Prado et al., 2009b).

In the present study, a traditional spectrophotometric method is used to assess the mediumterm effect of the herbicide paraquat on pigment content of the freshwater green microalga Chlamydomonas moewusii. Additionally, flow cytometry is used to characterize the response of microalgal cells to paraquat as regards several structural and physiological parameters (cell size and complexity, chlorophyll fluorescence and cell viability), in order to improve understanding of the effects and toxicity mechanisms of this herbicide. Paraquat concentrations selected for this study are known to affect the population growth of this microalga (Prado et al., 2009b) and they are below the recommended paraquat application rates for aquatic weed control that range between 0.4 and $7.8 \mu \mathrm{M}$ (Cochón et al., 2007 and Eisler, 1990) and below the expected environmental concentration calculated for this herbicide (about $3.1 \mu \mathrm{M}$ ) ( Wong, 2000).

\section{Materials and methods}

\subsection{Microalgal cultures}

C. moewusii Gerloff (Chlamydomonadaceae) was obtained from the Culture Collection of Algae and Protozoa of Dunstaffnage Marine Laboratory (Scotland, UK) (strain CCAP 11/5B) and was maintained in autoclaved ( $1 \mathrm{bar}, 121^{\circ} \mathrm{C}, 20 \mathrm{~min}$ ) Bristol medium ( Brown et al., 1967). The inoculum for the assays was taken from a 3-day-old stock culture, with the aim of using cells growing in a logarithmic phase for all experiments. Cultures were grown in autoclaved $500 \mathrm{ml}$ Pyrex glass bottles containing $300 \mathrm{ml}$ of sterile medium. Microalgal cultures were maintained at $18 \pm 1{ }^{\circ} \mathrm{C}$, illuminated with $70 \mu \mathrm{mol}$ photon $\mathrm{m}^{-2} \mathrm{~s}^{-1}$ under a dark:light cycle of $12: 12 \mathrm{~h}$ and continuously aerated for $96 \mathrm{~h}$. Initial cell density for each assay was $4 \times 10^{5}$ cells $\mathrm{ml}^{-1}$.

Based on previously carried-out concentration-response assays, paraquat was added to the growth media to create a range of different exposure concentrations, notably $50 \mathrm{nM}$ (lower than the $\mathrm{EC}_{50}$ ), 100 and $150 \mathrm{nM}$ (about the $\mathrm{EC}_{50}$ ), and $200 \mathrm{nM}$ (higher than the $\mathrm{EC}_{50}$ ) (Prado et al., 2009b). Paraquat stock solution (1 $\mathrm{mM})$ was prepared by dissolving granulated herbicide 
(Sigma; MW: 257.2) in distilled and sterilized water. Cultures without paraquat were also included as control. All cultures were carried out in triplicate.

\subsection{Photosynthetic pigment content}

The pigments were extracted from the concentrated algal sample in an aqueous solution of acetone $(90 \%, \mathrm{w} / \mathrm{v})$ and determined by measuring the absorbance of the extract using a Shimadzu UV-1700 spectrophotometer at appropriate wavelengths. The resulting absorbance measurements were translated to chlorophylls and carotenoids according to Jeffrey and Humphrey (1975) and Strickland and Parsons (1972), respectively.

\subsection{Flow cytometric analysis of microalgal cells}

Flow cytometric analysis of $C$. moewusiicells were performed in a Coulter Epics XL4 flow cytometer (Beckman Coulter Inc., Fullerton, CA, USA) equipped with an argon-ion excitation laser $(488 \mathrm{~nm})$, detectors of forward (FS) and side (SS) light scatter and four fluorescence detectors corresponding to four different wavelength intervals: 505-550 nm (FL1), 550-600 nm (FL2), 600-645 nm (FL3) and >645 nm (FL4). Forward scatter and red chlorophyll fluorescence histograms were used to characterize the microalgal population, setting gating levels in order to exclude non-microalgal particles. For each cytometric parameter investigated, at least $10^{4}$ gated cells were analysed per culture and fluorescence measurements were obtained in a logarithmic scale. Data were collected using listmode files and statistically analysed using the EXPO32 ADC software (Beckman Coulter Inc.).

\subsubsection{Cell size, complexity and chlorophyll fluorescence}

Since the forward light scatter (FS) is correlated with the size or volume of a cell or particle and the side light scatter (SS) is correlated with the intracellular complexity (Shapiro, 1995), aliquots of microalgal cultures were resuspended in phosphate buffered saline solution (PBS, pH 7.4) and analysed daily by flow cytometry to study the potential alterations in the cell size and intracellular complexity of $C$. moewusii cells for each culture up to $96 \mathrm{~h}$.

Similarly, the red autofluorescence (FL4 detector: 660-700 nm) of $C$. moewusii cells, related to chlorophyll $a$, was also analysed to study the potential changes in this pigment content, which allowed comparison with the pigment content determined spectrophotometrically.

For each analysed parameter, data were recorded in a logarithmic scale and results were expressed as mean values obtained from histograms in arbitrary units (a.u.).

\subsubsection{Cell viability}

In the present work, effects of paraquat on cell viability for C. moewusii cultures after $96 \mathrm{~h}$ of exposure were studied by means of two methods widely used to assess cell viability by flow cytometry, one staining cells with the fluorochrome propidium iodide $(\mathrm{PI})$ and the other with fluorescein diacetate (FDA). 
$\mathrm{PI}$ is a vital dye that intercalates with double-stranded nucleic acids to produce red fluorescence when excited with blue light. Due to its polarity, this fluorochrome is unable to pass through intact cell membranes. However, when a cell dies and integrity of cell membrane fails, $\mathrm{PI}$ is able to enter and stain nucleic acids (Ormerod, 1990). Fluorescence was recorded in a logarithmic scale between 605 and $635 \mathrm{~nm}$ (FL3 detector). In this way, PI can be used to discriminate between live non-fluorescent cells and non-viable fluorescent cells. Aliquots of $2 \times 105$ cells $\mathrm{ml}-1$ were resuspended in PBS and stained with PI at a final concentration of $2.5 \mu \mathrm{g} \mathrm{ml}-1$ for $10 \mathrm{~min}$ at room temperature and in darkness (Prado et al., 2008). Many authors have used FDA staining as a method to assess viability in microalgal cells exposed to cytotoxic conditions (Bentley-Mowat, 1982, Lage et al., 2001 and Nancharaiah et al., 2007). FDA is a nonfluorescent, non-polar and lipophilic molecule that diffuses across cell membranes. After entering the cell, its acetate residues are cleaved off by non-specific esterases and the polar hydrophilic fluorescent product fluorescein is retained by cells with intact plasma membranes, while cells with altered membranes, as non-viable cells are, rapidly leak the dye, even if they retain some residual esterase activity, and remain non-fluorescent (Lage et al., 2001). For this reason, fluorescein fluorescence emission can be used as an indicator of metabolic activity in the cell and indirectly also as a viability marker. FDA-derived fluorescence was recorded in a logarithmic scale by FL1 detector $(505-550 \mathrm{~nm})$. Aliquots of $2 \times 10^{5} \mathrm{cell} \mathrm{ml}^{-1}$ resuspended in PBS were incubated with FDA at a final concentration of $50 \mathrm{ng} \mathrm{ml}^{-1}$ for $15 \mathrm{~min}$ at room temperature and in darkness (Prado et al., 2008).

Results are expressed as the percentage of viable cells $v s$. the total amount of cells analysed by flow cytometry.

Thermal death by microwave heating was included as a control of both probes.

\subsection{Data analysis}

Mean and standard deviation values were calculated for each treatment from three independent replicate cultures. Data are given as mean values \pm standard error of the means. To determine significant differences among test concentrations, data were statistically analysed by an overall one-way analysis of variance (ANOVA) using the SPSS 16.0 software. A $p$ value $<0.05$ was considered statistically significant. When significant differences were observed, means were compared by the multiple-range Duncan test.

\section{Results}

\subsection{Photosynthetic pigment content}

After $96 \mathrm{~h}$ of exposure to all paraquat concentrations assayed, chlorophyll $a$ and $b$ contents of $C$. moewusibiomass were significantly reduced with respect to control cultures $(p<0.05)$. This effect was concentration-dependent, in such a way that microalgae exposed to the highest concentration assayed showed a reduction of chlorophyll a content of about $90 \%$ with respect to 
the control. As shown in Fig. 1, from 100 nM paraquat chlorophyll a was slightly more affected than chlorophyll b ( Fig. 1).

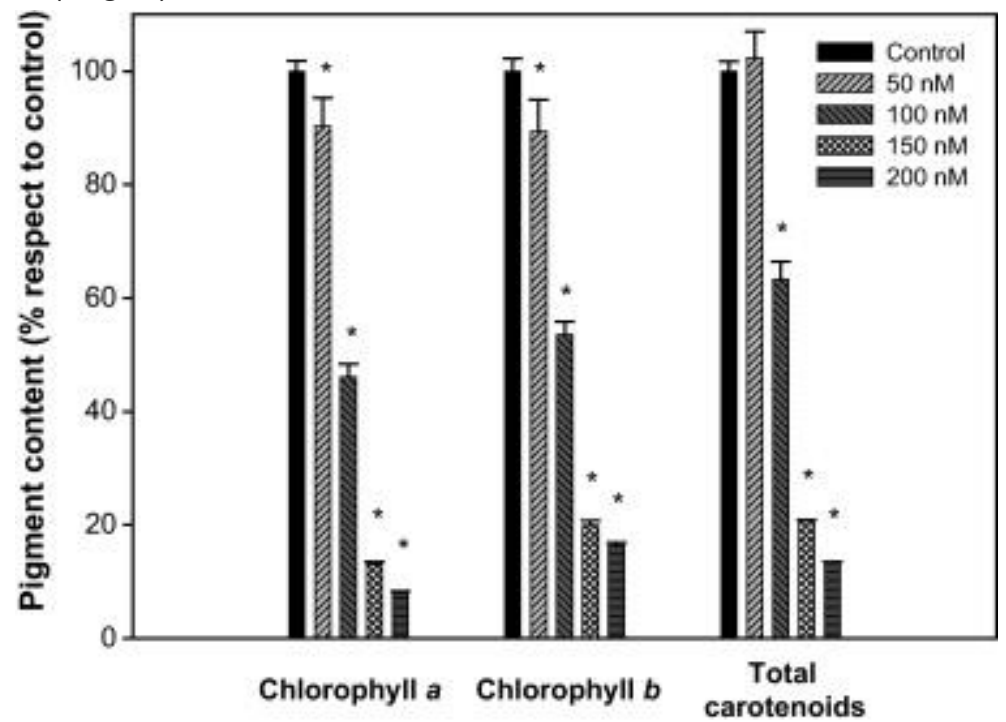

Fig. 1.

Photosynthetic pigment content, expressed as percentage with respect to control, of $C$. moewusiicultures after $96 \mathrm{~h}$ of exposure to different paraquat concentrations. Asterisks indicate statistically significant differences with respect to the values of control cultures $(p<0.05)$.

Total carotenoid content was also affected by the addition of the herbicide, showing a significant reduction with respect to control $(p<0.05)$ in cultures exposed to paraquat concentrations of $100 \mathrm{nM}$ or higher. However, biomass of cultures exposed to the lowest concentration assayed, $50 \mathrm{nM}$, showed a total carotenoid content which was not significantly different to that of the control $(p>0.05)$ ( Fig. 1).

\subsection{Chlorophyll fluorescence, cell size and complexity}

Chlorophyll fluorescence or autofluorescence of $C$. moewusii cells was affected by the addition of paraquat to culture medium. Using flow cytometry we could observe the presence of a subpopulation of chlorotic cells, which have low values of autofluorescence, in cultures subjected to $48 \mathrm{~h}$ of exposure to high herbicide concentrations (150 and $200 \mathrm{nM}$ ) (Fig. 2). Percentage of chlorotic cells increased with paraquat concentration and time of exposure, so that about $80 \%$ of cells in cultures exposed to $200 \mathrm{nM}$ of paraquat after $96 \mathrm{~h}$ were chlorotic cells. However, cultures exposed to the lowest concentration assayed, $50 \mathrm{nM}$, did not show chlorotic cells at any time of the assay ( Fig. 2). 

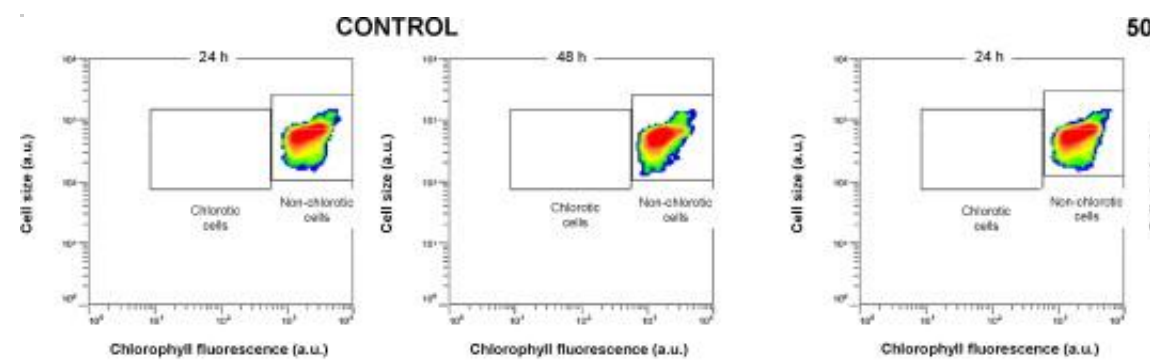

$50 \mathrm{nM}$
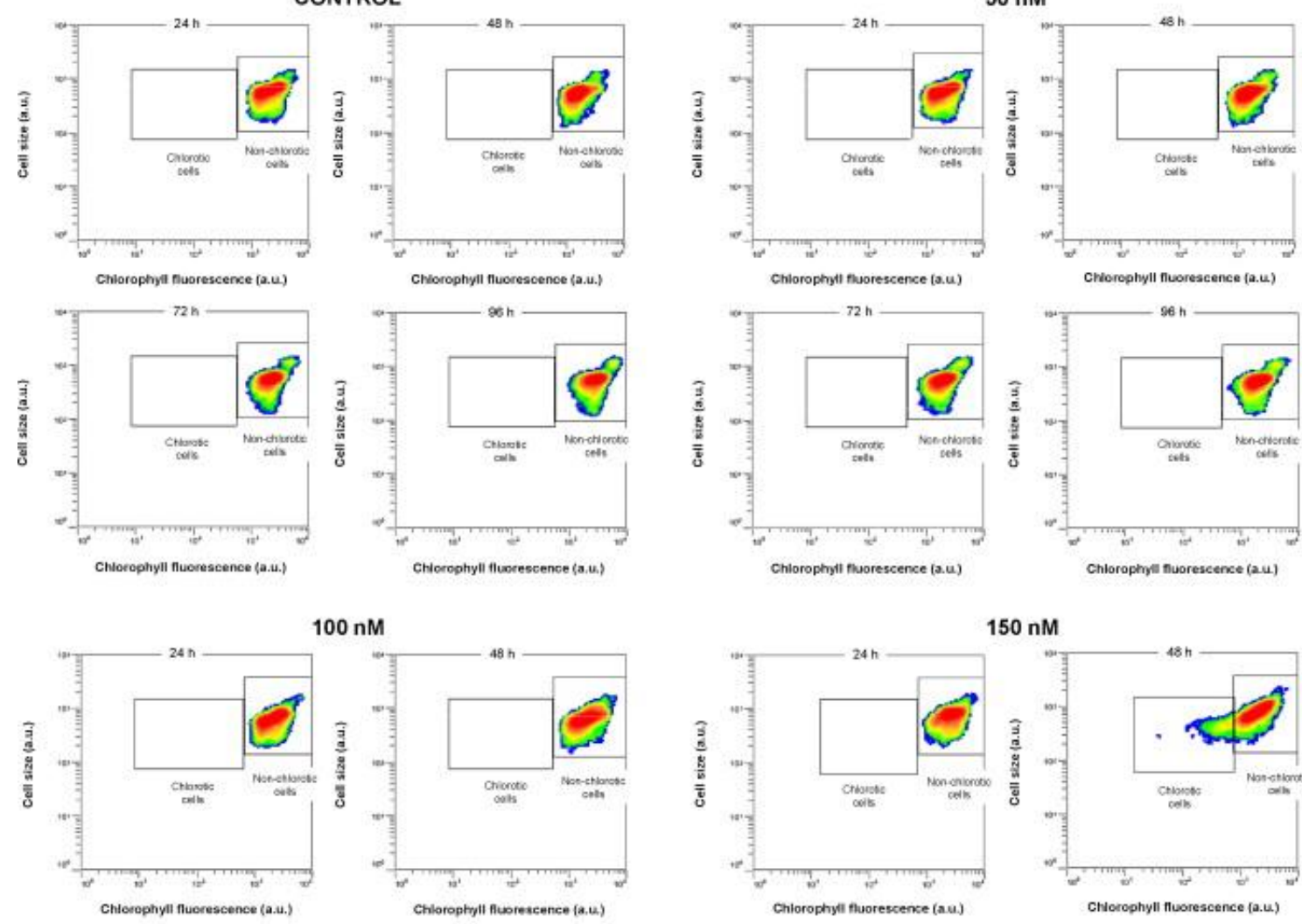

$100 \mathrm{nM}$
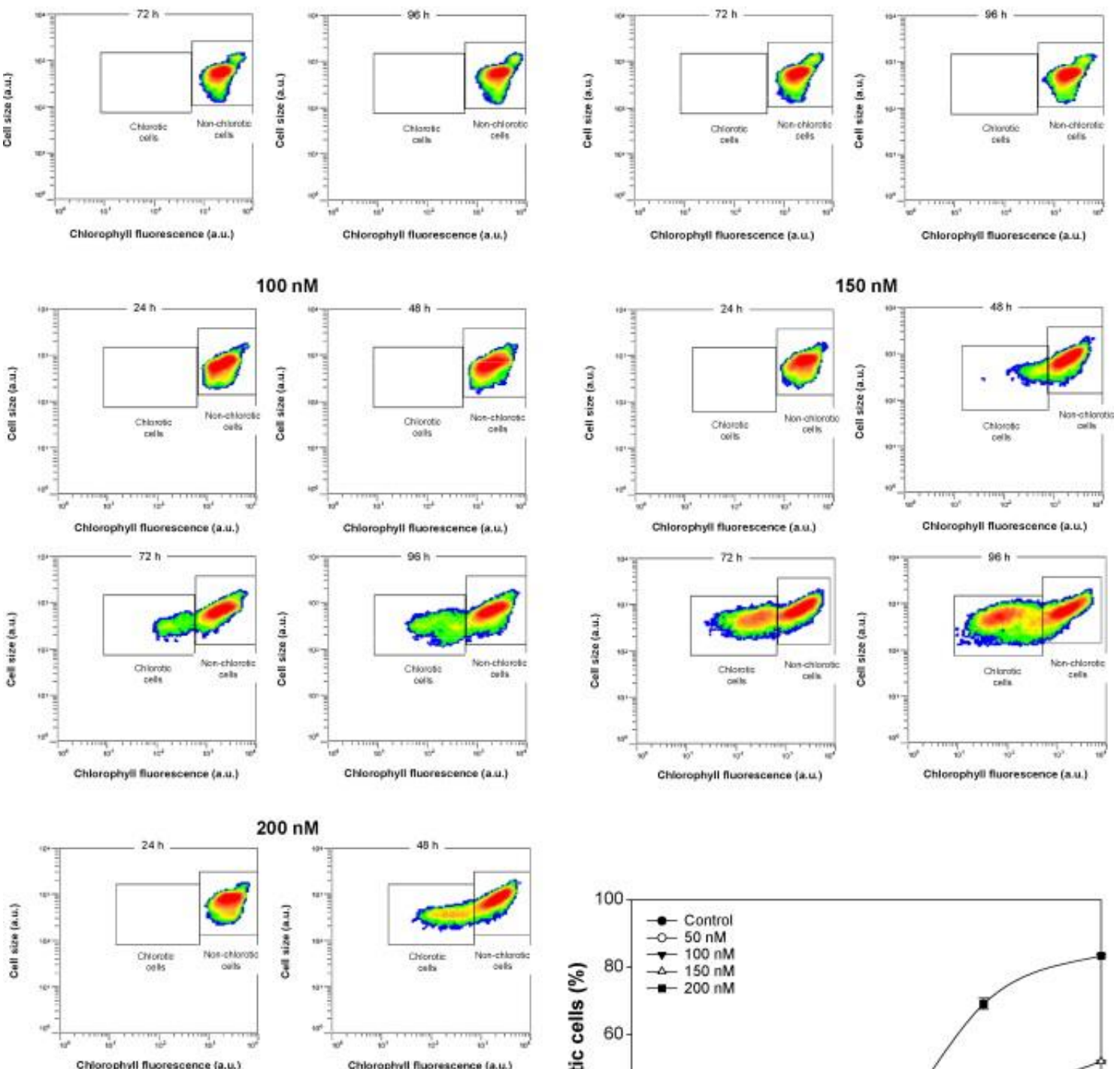

$200 \mathrm{nM}$
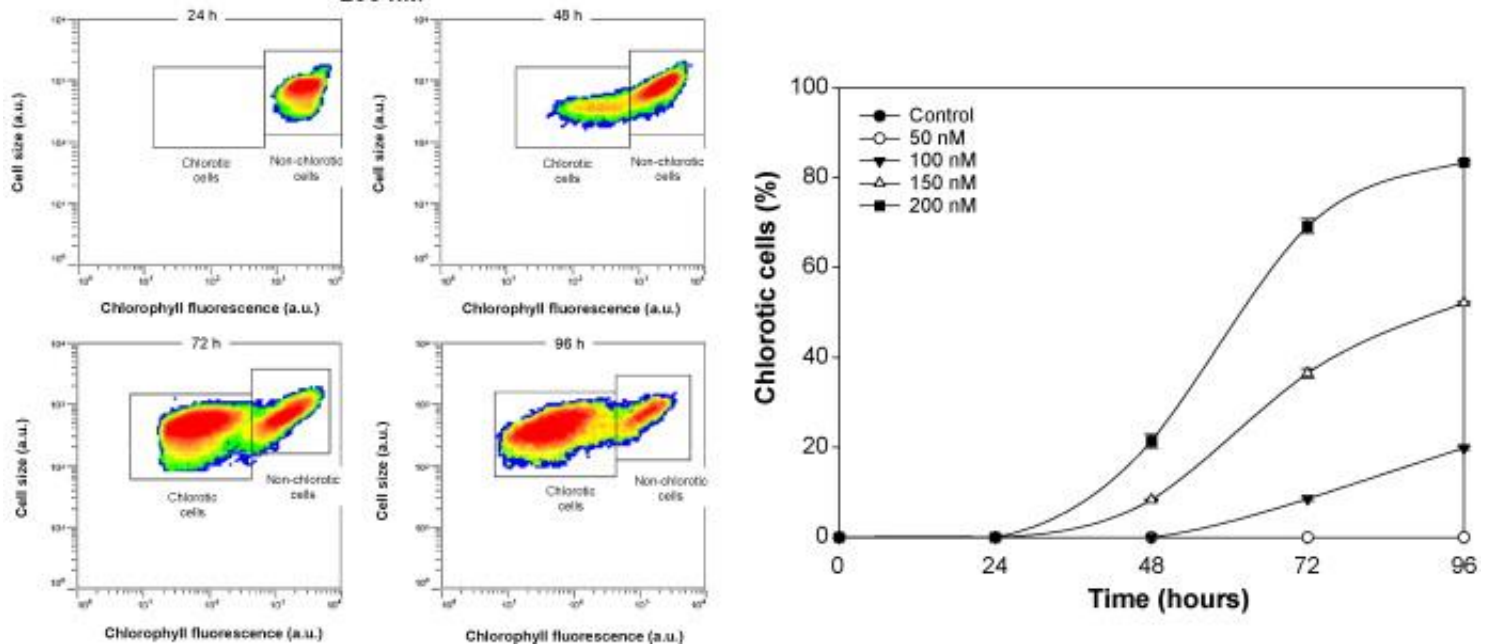

Fig. 2.

Arbitrary units of chlorophyll autofluorescence $v s$. cell size for $C$. moewusii cultures for all the paraquat concentrations assayed. Figures distinguish chlorotic from non-chlorotic cells and graph shows percentage of the appearance of chlorotic cells for each culture along the experiment. 
The independent analysis of chlorotic and non-chlorotic cells allowed us to observe that cell size and complexity of chlorotic cells were significantly lower $(p<0.05)$ than those presented by nonchlorotic cells of the corresponding culture ( Fig. 3A and B). After $96 \mathrm{~h}$ of exposure to a paraquat concentration of $100 \mathrm{nM}$, non-chlorotic cell size was approximately twice the size of chlorotic cells. In any case, chlorotic cells, for all paraquat concentrations studied, showed a significant decrease of cell size signal with respect to control cells $(p<0.05)$. However, this cell size signal increased with herbicide concentration, so that after $96 \mathrm{~h}$ chlorotic cells exposed to $200 \mathrm{nM}$ showed a non-significantly different cell size from that of control cells $(p>0.05)$ ( Fig. 3A). Complexity of chlorotic cells in cultures exposed to 150 and $200 \mathrm{nM}$ was maintained higher than that observed for control cells, in a concentration and time dependent manner, so that after $96 \mathrm{~h}$ these cells reached the complexity level of non-chlorotic cells in cultures exposed to the highest concentration assayed ( $p>0.05)$ ( Fig. 3B).

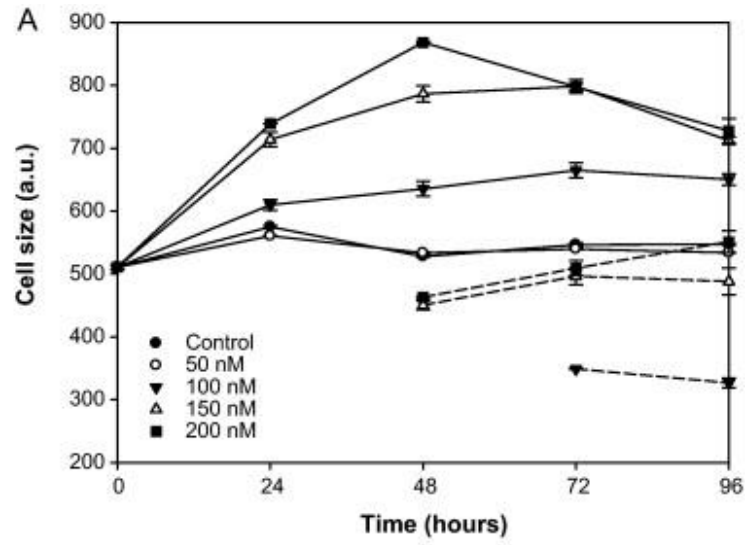

Fig. 3.

Arbitrary units of cell size (A), cellular complexity (B) and chlorophyll fluorescence (corrected by cell size) (C) in C. moewusiicultures exposed to different paraquat concentrations as a function of time. Dashed lines represent the chlorotic subpopulation and continuous lines represent the non-chlorotic subpopulation.
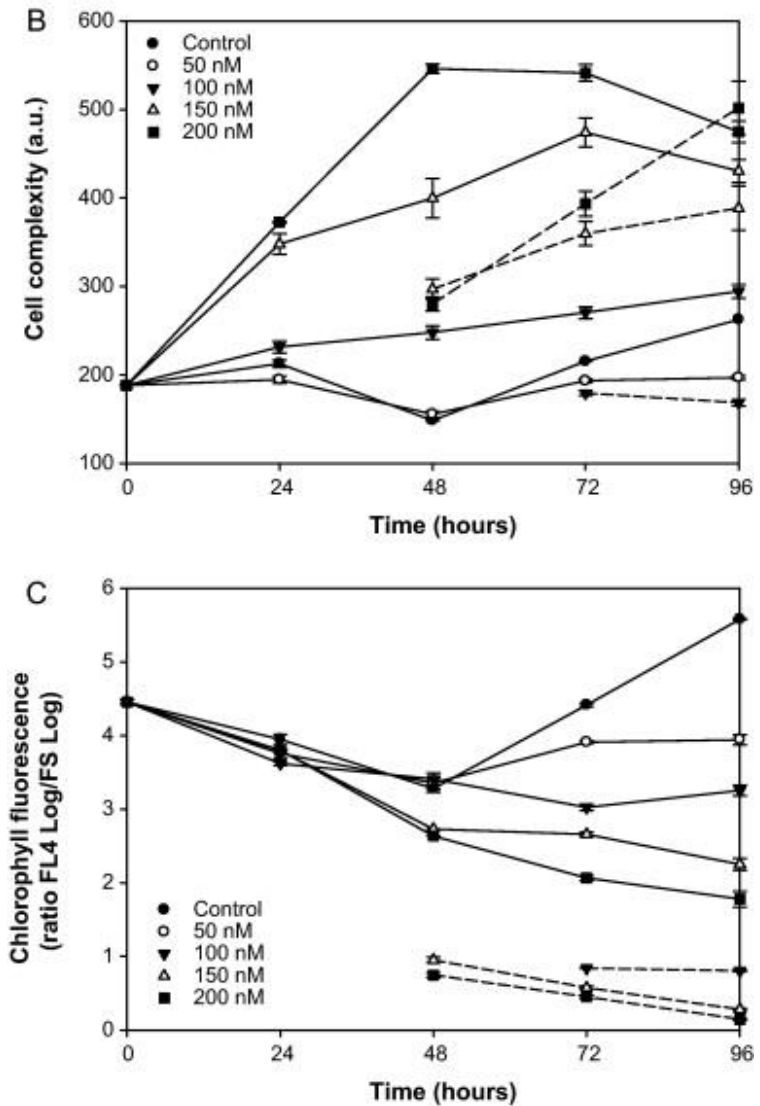
When analysing the non-chlorotic cell subpopulations exposed to paraquat, a significant increase $(p<0.05)$ of cell size and complexity as a function of herbicide concentration and exposure time was observed. During the last hours of assay these cell morphological parameters showed a decrease in those cultures exposed to the highest paraquat concentrations ( Fig. 3A and B). Maximum differences with respect to values shown by control cells were observed at $48 \mathrm{~h}$, when non-chlorotic cells of cultures exposed to $200 \mathrm{nM}$ showed a size that was almost twice that of control cells ( Fig. 3A) and a complexity that was nearly four times that observed in control cultures ( Fig. 3B).

The possibility of analysing separately chlorotic and non-chlorotic subpopulations in each culture allowed us to observe that chlorophyll fluorescence of non-chlorotic cells was also reduced by addition of paraquat in a concentration and time dependent way, with respect to the values observed in control cultures. After $96 \mathrm{~h}$, all cultures exposed to paraquat showed a cell autofluorescence significantly reduced with respect to control cells $(p<0.05)$ ( Fig. 3C). Because differences were observed in cell size, differences observed in autofluorescence intensities could be just a reflection of this cell size difference. To account for this, autofluorescence values were corrected by cell size (FL4/FS) ( Fig. 3C).

\subsection{Cell viability}

Both $\mathrm{PI}$ and FDA assays pointed to a significant reduction of cell viability $(p<0.05)$ induced by $96 \mathrm{~h}$ of exposure to a paraquat concentration of $100 \mathrm{nM}$ or higher, this effect ocurring in a concentration dependent manner. However, results obtained on the FDA staining method indicated a reduction of cell viability more marked than those obtained based on the PI staining method, and this difference was more evident at high paraquat concentrations ( Table 1).

Table 1.

Cell viability in C. moewusii cultures after $96 \mathrm{~h}$ of exposure to different paraquat concentrations, determined by flow cytometry based on staining cells with PI or FDA, and expressed as the percentage of viable cells with respect to the total amount of cells analysed.

\begin{tabular}{l|l|l} 
Paraquat concentration $(\mathrm{nM})$ & \multicolumn{2}{l}{ Cell viability $(\%)$} \\
\cline { 2 - 3 } & PI(-) cells & FDA(+) cells \\
\hline 0 & $98.97 \pm 0.10$ & $99.39 \pm 0.03$ \\
\hline 50 & $98.47 \pm 0.28$ & $98.54 \pm 0.09$ \\
\hline 100 & $85.54 \pm 0.67^{*}$ & $80.64 \pm 0.27^{*}$ \\
\hline 150 & $63.70 \pm 2.46^{*}$ & $32.66 \pm 2.64^{*}$ \\
\hline 200 & $44.60 \pm 1.58^{*}$ & $8.35 \pm 0.83^{*}$ \\
\hline * & & \\
\hline Significant differences with respect to the values of control cultures $(p<0.05)$.
\end{tabular}

Analysing separately chlorotic and non-chlorotic subpopulations, it was shown that differences observed between results obtained based on both cytometric protocols were due to chlorotic cell behaviour. Chlorotic cells are FDA(-) (considered non-viable, metabolically non-active) cells 
(Fig. 4). However, in chlorotic subpopulation $\mathrm{PI}(-)$ cells (considered viable cells) were present to a certain extent (Fig. 5).
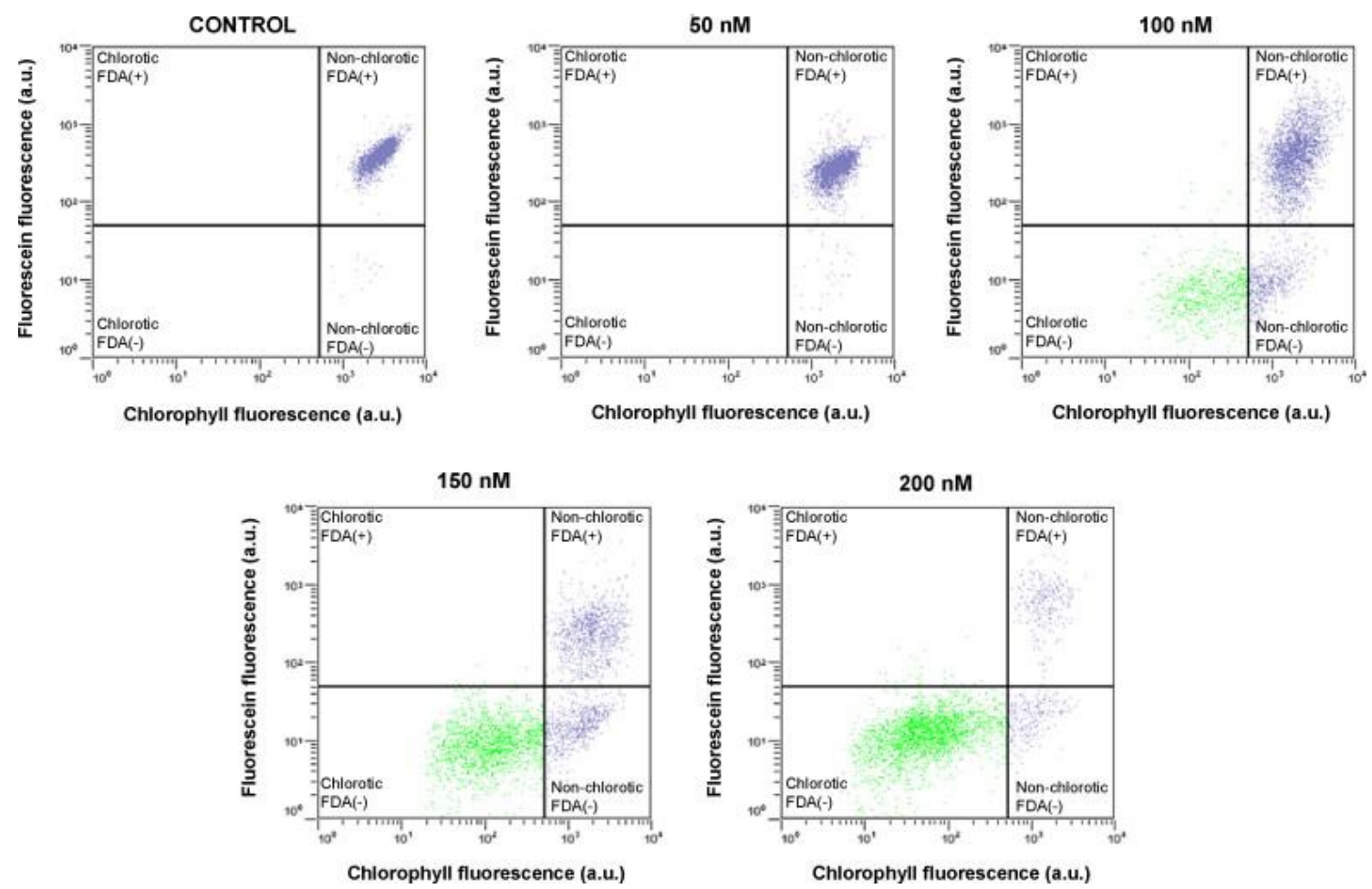

Fig. 4.

Cell viability analysed by flow cytometry based on staining cells with FDA. Biparametric histograms show the chlorophyll fluorescence (a.u.) vs. the fluorescein fluorescence (a.u.) for $C$. moewusii cultures exposed to different paraquat concentrations during $96 \mathrm{~h}$, after incubation with FDA under conditions described in Section 2. Chlorotic and non-chlorotic subpopulations are shown in green and blue, respectively. (For interpretation of the references to colour in this figure legend, the reader is referred to the web version of the article.)

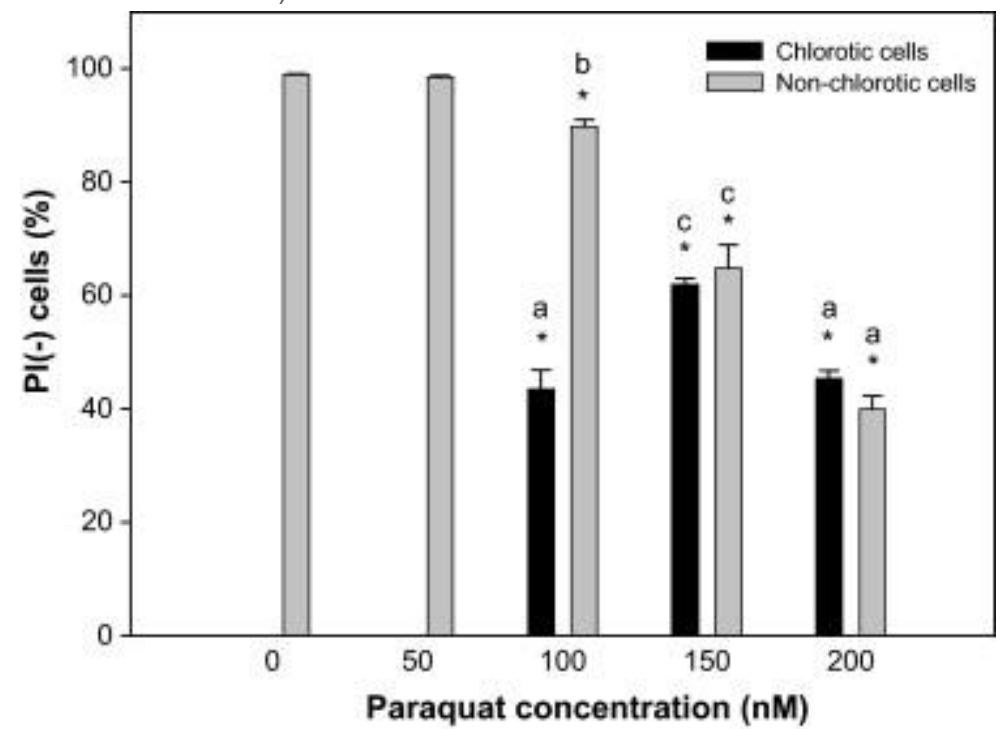

Fig. 5.

Cell viability in C. moewusii cultures after $96 \mathrm{~h}$ of exposure to different paraquat concentrations, expressed as the percentage of $\mathrm{PI}(-)$ (viable) cells for each subpopulation, chlorotic and non-chlorotic, differentiated. Asterisks indicate statistically significant differences with respect to the values of control 
cultures $(p<0.05)$. Statistically significant differences between chlorotic and non-chlorotic subpopulations and/or treatments were indicated by different lowercase letters $(p<0.05)$.

Analysis of non-chlorotic subpopulation showed that the percentage of viable cells decreased with the increase of paraquat concentration in culture, and results obtained based on both cytometric protocols are comparable, without significant differences $(p>0.05)$ between percentages of $\mathrm{FDA}(+)$ and $\mathrm{PI}(-)$ cells for the different cultures taking into account only nonchlorotic cells ( Fig. 5 and Fig. 6). In cultures exposed to the lowest paraquat concentration assayed, $50 \mathrm{nM}$, in which subpopulation of chlorotic cells was not differentiated, cell viability was not affected, while in cultures exposed to $200 \mathrm{nM}$ more than $50 \%$ of non-chlorotic cells were non-viable cells. This concentration dependent reduction of cell viability is not shown in results obtained for chlorotic subpopulation based on PI assay, so that there were not significant differences $(p>0.05)$ between exposed cultures but rather an increase of cell viability $(\% \mathrm{PI}(-)$ cells) was observed in cultures exposed to $150 \mathrm{nM}$ paraquat with respect to those exposed to $100 \mathrm{nM}$ ( Fig. 5).

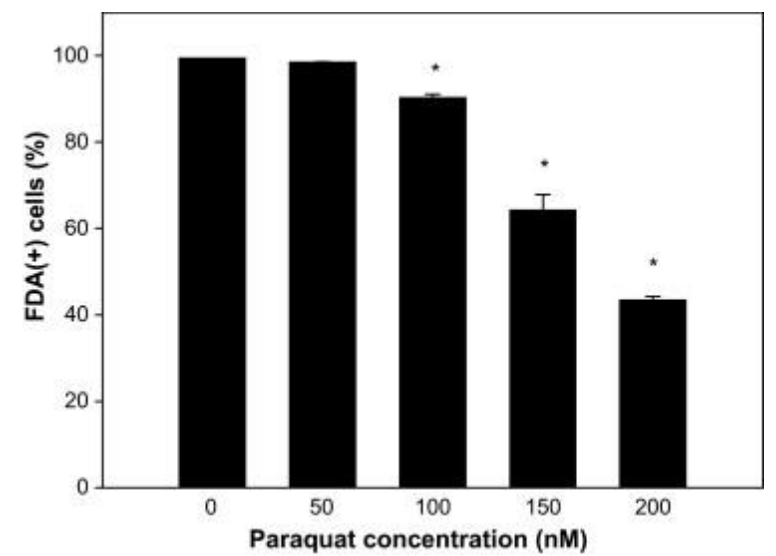

Fig. 6.

Cell viability of non-chlorotic cells from $C$. moewusii cultures after $96 \mathrm{~h}$ of exposure to different paraquat concentrations, expressed as the percentage of FDA $(+)$ (viable) cells with respect to the total amount of non-chlorotic cells analysed by flow cytometry. Asterisks indicate significant differences with respect to the values of control cultures $(p<0.05)$.

\section{Discussion}

Standardised algal growth bioassays remain the preferred technique for assessment of phytotoxic effects in most ecotoxicological studies (Debelius et al., 2008, Nie et al., 2009, Pereira et al., 2009 and van Wezel and van Vlaardingen, 2004). These tests provide important ecological information, but results do not allow us to know about the physiological causes that can result in growth inhibition, i.e., do not offer information regarding the mode of toxic action. Because of this, flow cytometry, a technique that allows us to study different morphological and physiological properties of single cells, has been introduced as a useful tool in toxicity tests with microalgae ( Franqueira et al., 2000). In the present work, we could characterize the response of $C$. moewusii cells to the worldwide used herbicide paraquat, at concentrations known to affect microalgal growth ( Prado et al., 2008 and Prado et al., 2009b), using flow cytometry to 
analyse the effects of paraquat on different inherent cell properties and cell physiological status based on membrane stability. Results obtained indicated that this herbicide affects all these parameters and the effects observed can be explained by the generation of oxidative stress.

Phototrophic organisms like microalgae show a natural autofluorescence provided by their pigments, mainly by chlorophyll. Chlorophyll a fluorescence alterations have been used to study the physiological state of microalgal cells exposed to different stress factors ( Chalifour et al., 2009, Ekelund and Aronson, 2007,Geoffroy et al., 2007, González-Barreiro et al., 2004, Hadjoudja et al., 2009, Muller et al., 2008, Nguyen-Ngoc et al., 2009 and Sobrino et al., 2004). Results obtained in this work showed that paraquat affects chlorophyll of $C$. moewusii cells, since it caused a drastic reduction of chlorophyll fluorescence in a percentage of microalgal cells dependent on paraquat concentration and time of exposure to the herbicide ( Fig. 2). These cells were identified as chlorotic cells since their drastic reduction of chlorophyll autofluorescence seemed to indicate an almost total loss of these photosynthetic pigments. Analysing separately non-chlorotic cells we could also observe a reduction of its chlorophyll fluorescence with paraquat concentration and exposure time increase ( Fig. $3 \mathrm{C}$ ). It is probable that the progressive reduction of cell autofluorescence was related to an oxidative breakdown of chlorophyll as a consequence of the generation of reactive oxygen species by paraquat action ( Ekmekci and Terzioglu, 2005).

Spectrophotometric determination of photosynthetic pigment content indicated a significant reduction of chlorophyll content $(p<0.05)$ in $C$. moewusii cells exposed to any of the paraquat concentrations assayed, although it is more evident at high herbicide concentrations ( Fig. 1), in accordance with results obtained by flow cytometry. A decrease in carotenoid content of microalgal cells was also observed, although not in cultures exposed to the lowest concentration assayed ( Fig. 1), revealing that these pigments have a higher tolerance to the herbicide action than chlorophylls. In these cultures, we even observed a slight increase in carotenoid content of biomass, which could be an indicator of the protective role of these pigments against oxidative stress, since carotenoids are known to be potent quenchers of reactive oxygen species, particularly singlet oxygen ( Ünyayar et al., 2005). In addition to the known mode of action of paraquat, as a final acceptor of the photosynthetic electrons, the inhibitory action on an essential enzyme for chlorophyll biosynthesis has also been observed ( Patras and Artenie, 2007), but this action would not explain the simultaneous reduction of carotenoid content, so oxidative degradation is the most probable cause of the photosynthetic pigment content reduction observed in C. moewusii after $96 \mathrm{~h}$ of exposure to the herbicide paraquat. Inhibitory effects of paraquat on photosynthetic pigments have been observed in different phototrophic organisms ( Kaur et al., 2002, Qian et al., 2009 and Wong, 2000).

Analysing separately chlorotic and non-chlorotic cells by flow cytometry, it was observed that chlorotic cells showed a significantly lower $(p<0.05)$ cell size and complexity in comparison with the non-chlorotic cells in cultures where both cell types were present ( Fig. $3 \mathrm{~A}$ and B). This feature may be indicative of the fact that these cells are non-viable cells (Vamanu et al., 2008). With regard to non-chlorotic cells, they showed a significant increase in these morphological 
properties with respect to control cells $(p<0.05)$, generally in a paraquat concentration and time dependent manner ( Fig. 3A and B). We could relate this effect to the growth inhibition induced by paraquat in cultures of this microalga observed in previous studies ( Prado et al., 2008 and Prado et al., 2009b), leading to the formation of palmelloid colonies due to the incapacity to finish cell division. Alterations in cell membranes as a consequence of oxidative stress could lead to osmotic alterations which in turn influence the cell volume, and to a cell component degradation which is reflected by an intracellular complexity increase ( Bray et al., 1993).

A lethal effect of this herbicide has been observed in studies with different phytoplanktonic organisms (Franqueira et al., 1999, Palmer et al., 2002 and Sakthivel et al., 2009). In the present study we employed flow cytometry to analyse cell viability in C. moewusii cultures exposed to paraquat, by means of two methods based on changes occurring in membrane integrity when a cell dies. Results obtained based on both cell viability assays showed a similar pattern, i.e., a reduction of cell viability with the increase of paraquat concentration and exposure time to the herbicide ( Table 1). The biochemical mechanism of paraquat toxicity, characterized by the generation of oxygen free radicals, could explain the increase in percentage of cells which have lost their membrane integrity observed in cultures exposed to high paraquat concentrations, since reactive oxygen species have been implicated in the initiation of membrane damage by lipid peroxidation ( Chagas et al., 2008 and Yu, 1994). In fact, lipid peroxidation, i.e., the oxidative degeneration of polyunsaturated fatty acids, has been suggested as a potential mechanism of paraquat toxicity ( Palmer et al., 2002, Qian et al., 2009 and Suntres, 2002).

In spite of the similar pattern showed by results obtained through both methods, we observed that reduction of cell viability obtained by FDA assay is more drastic than that obtained by PI assay, especially in cultures exposed to paraquat concentrations of more than $50 \mathrm{nM}$ (Table 1). This could be attributed to the assay itself, since both cytometric methods allow distinguishing between cells with an intact plasma membrane (viable) and cells which have lost the membrane integrity (non-viable), but FDA assay may also include as non-viable cells those with an intact membrane but with metabolic alterations so that they do not show esterase activity. In fact, Jones, 1987a and Jones, 1987b reported that cells are deactivated before true cell death occurs. Another probable explanation to the differences observed between the cell viability assays arises when separately analysing chlorotic and non-chlorotic subpopulations. Taking into account only non-chlorotic cells in the different cultures, it could be observed that there were not significant differences $(p>0.05)$ between viability percentages obtained based on PI and FDA ( Fig. 5 and Fig. 6), demonstrating that the observed difference was due to the chlorotic cell behaviour. All chlorotic cells were FDA(-), i.e., non-viable based on FDA assay ( Fig. 4), while after staining with PI we observed that some percentage of chlorotic cells were not stained with this fluorochrome, which could lead us to conclude these cells were viable ( Fig. 5). However, it is probable that the presence of chlorotic cells not stained with $\mathrm{PI}$ is not due to these cells having their membrane intact, but rather, to their extremely damaged nucleid acids as a consequence of oxidative stress ( Perl-Treves and Perl, 2002), which does not allow the 
fluorochrome to intercalate with them, so that it cannot be retained inside the cell. This would explain why the percentage of $\mathrm{PI}(-)$ cells in chlorotic subpopulation did not show the logical reduction trend with herbicide concentration increase but rather increased in cultures with high concentrations ( Fig. 5). Regarding this, we have previously reported the genotoxicity of paraquat on C. moewusii by means of the comet assay ( Prado et al., 2009a). In this way, we considered that cell viability results obtained based on FDA were more reliable than those obtained based on PI, so that chlorotic cells would be non-viable cells. In fact, mortality in phytoplankton results in rapid degradation of photopigments and membrane damages would occur before drastic pigment degradation ( Veldhuis et al., 2001). Pouneva (1997) established that chlorophyll autofluorescence could be recommended as the most convenient method for differentiating living and dead algal cells, since the irreversible damage of the cell is connected to a disappearance of its fluorescence.

On the other hand, cell death is associated with a rapid decrease in the ability of a cell to scatter light simultaneously in the forward (FS) and side (SS) angle direction, as a consequence of a plasma membrane rupture and leakage of the cell components (Darzynkiewicz et al., 1992), so that non-viable cells should be characterized by a reduced size and complexity, properties that were shown by chlorotic cells in the present study.

Flow cytometry has allowed us to characterize the response of $C$. moewusiicells to the herbicide paraquat, providing the possibility of distinguishing subpopulations of cells that respond differently to the herbicide exposure, which allows us to study these cells separately, in comparison with analysis using traditional techniques based on population bulk measurements.

\section{Acknowledgements}

This work was supported by research projects from Ministerio de Educación e Innovación of the Spanish Government (CGL2004-02037) and Xunta de Galicia (Spain) (08MDS020103PR). R. Prado acknowledges a F.P.U. fellowship from the Spanish Ministerio de Educación y Ciencia.

\section{References}

E.A. Ananieva, K.N. Christov, L.P. Popova

Exogenous treatment with salicylic acid leads to increased antioxidant capacity in leaves of barley plants exposed to paraquat

J. Plant Physiol., 161 (2004), pp. 319-328

\section{J.A. Bentley-Mowat}

Application of fluorescence microscopy to pollution studies on marine phytoplankton

Bot. Mar., 25 (1982), pp. 203-204

P. Bi Fai, A. Grant, B. Reid

Chlorophyll a fluorescence as a biomarker for rapid toxicity assessment

Environ. Toxicol. Chem., 26 (2007), pp. 1520-1531 
D.F. Bray, J.R. Bagu, K. Nakamura

Ultrastructure of Chlamydomonas reinhardtii following exposure to paraquat: comparison of wild type and a paraquat-resistant mutant

Can. J. Bot., 71 (1993), pp. 174-182

T.E. Brown, F.L. Richardson, M.L. Vaughn

Development of red pigmentation in Chlorococcum wimmeri (Chlorophyta:Chlorococcales)

Phycologia, 6 (1967), pp. 167-184

A.C. Cochón, A.B. Della Penna, G. Kristoff, M.N. Piol, L.C. San Martín de Viale, N.R. Verrengia Guerrero Differential effects of paraquat on oxidative stress parameters and poliamine levels in two freshwater invertebrates

Ecotoxicol. Environ. Saf., 68 (2007), pp. 286-292

M. Couderchet, G. Vernet

Pigments as biomarkers of exposure to the vineyard herbicide flazasulfuron in freshwater algae

Ecotoxicol. Environ. Saf., 55 (2003), pp. 271-277

R.M. Chagas, J.A.G. Silveira, R.V. Ribeiro, V.A. VItorello, H. Carrer

Photochemical damage and comparative performance of superoxide dismutase and ascorbate peroxidase in sugarcane leaves exposed to paraquat-induced oxidative stress

Pestic. Biochem. Physiol., 90 (2008), pp. 181-188

A. Chalifour, P.A. Spear, M.H. Boily, C. DeBlois, I. Giroux, N. Dassylva, P. Juneau

Assessment of toxic effects of pesticide extracts on different green algal species by using chlorophyll a fluorescence

Toxicol. Environ. Chem., 91 (2009), pp. 1315-1329

M.A. Daam, A.M.F. Rodrigues, P.J. Van den Brink, A.J.A. Nogueira

Ecological effects of the herbicide linuron in tropical freshwater microcosms

Ecotoxicol. Environ. Saf., 72 (2009), pp. 410-423

Z. Darzynkiewicz, S. Bruno, G. Del Bino, W. Gorczyca, M.A. Hotz, P. Lassota, F. Traganos

Features of apoptotic cells measured by flow cytometry

Cytometry, 13 (1992), pp. 795-808

M.E. De Lorenzo, L.A. Taylor, S.A. Lund, P.L. Pennington, E.D. Strozier, M.H. Fulton

Toxicity and bioconcentration potential of the agricultural pesticide endosulfan in phytoplankton and zooplankton

Arch. Environ. Contam. Toxicol., 42 (2002), pp. 173-181

View Record in Scopus

B. Debelius, J.M. Forja, A. Del Vals, L.M. Lubián 
Effect of linear alkylbenzene sulfonate (LAS) and atrazine on marine microalgae

Mar. Pollut. Bull., 57 (2008), pp. 559-568

J.W. Deneer

Toxicity of mixtures of pesticides in aquatic systems

Pest Manag. Sci., 56 (2000), pp. 516-520

N.G.A. Ekelund, K.A. Aronson

Changes in chorophyll a fluorescence in Euglena gracilis and Chlamydomonas reinhardtii after exposure to wood-ash

Environ. Exp. Bot., 59 (2007), pp. 92-98

Y. Ekmekci, S. Terzioglu

Effects of oxidative stress induced by paraquat on wild and cultivated wheats

Pestic. Biochem. Physiol., 83 (2005), pp. 69-81

Article

R. Eisler

Paraquat hazards to fish, wildlife, and invertebrates: a synoptic review Contaminant Hazard Reviews

U. S. Fish Wildlife Serv. Biol. Rep., 85 (1.22) (1990), p. 28

P. Eullaffroy, G. Vernet

The F684/F735 chlorophyll fluorescence ratio: a potential tool for rapid detection and determination of herbicide phytotoxicity in algae

Water Res., 37 (2003), pp. 1983-1990

M. Fatima, S.N.M. Mandiki, J. Douxfils, F. Silvestre, P. Coppe, P. Kestemont

Combined effects of herbicides on biomarkers reflecting immune-endocrine interactions in goldfish: immune and antioxidant effects

Aquat. Toxicol., 81 (2007), pp. 159-167

D. Franqueira, A. Cid, E. Torres, M. Orosa, C. Herrero

A comparison of the relative sensitivity of structural and functional cellular responses in the alga Chlamydomonas eugametos exposed to the herbicide paraquat

Arch. Environ. Contam. Toxicol., 36 (1999), pp. 264-269

D. Franqueira, M. Orosa, E. Torres, C. Herrero, A. Cid

Potential use of flow cytometry in toxicity studies with microalgae

Sci. Total Environ., 247 (2000), pp. 119-126

L. Geoffroy, R. Gilbin, O. Simon, M. Floriani, C. Adam, C. Pradines, L. Cournac, J. Garnier-Laplace Effect of selenate on growth and photosynthesis of Chlamydomonas reinhardtii

Aquat. Toxicol., 83 (2007), pp. 149-158 


\section{O. González-Barreiro, C. Rioboo, A. Cid, C. Herrero}

Atrazine-induced chlorosis in Synechococcus elongatus cells

Arch. Environ. Contam. Toxicol., 46 (2004), pp. 301-307

S. Hadjoudja, C. Vignoles, V. Delucht, J.F. Lenain, A.H. Le Jeune, M. Baudu

Short term copper toxicity on Microcystis aeruginosa and Chlorella vulgaris using flow cytometry

Aquat. Toxicol., 94 (2009), pp. 255-264

M. Ibáñez, Y. Picó, J. Mañes

Influence of organic matter and surfactans on solid-phase extraction of diquat, paraquat and difenzoquat from waters

J. Chromatogr. A, 727 (1996), pp. 245-252

\section{A. Jamers, W. De Coen}

Effect assessment of the herbicide paraquat on a green alga using differential gene expression and biochemical biomarkers

Environ. Toxicol. Chem., 29 (2010), pp. 893-901

\section{S.W. Jeffrey, G.F. Humphrey}

New spectrophotometric equations for determining chlorophylls a, b, c1 and c2 in higher plants, algae and natural phytoplankton

Biochem. Physiol. Pflanz., 167 (1975), pp. 191-194

\section{F.J. Jochem}

Probing the physiological state of phytoplankton at the single-cell level

Sci. Mar., 64 (2000), pp. 183-195

R.P. Jones

Measures of yeast and deactivation and their meaning: part I

Process Biochem., 22 (1987), pp. 117-128

R.P. Jones

Measures of yeast and deactivation and their meaning: part II

Process Biochem., 22 (1987), pp. 130-134

M. Kaur, A.S. Ahluwalia, S. Dahuja

Toxicity of a rice field herbicide in a nitrogen fixing alga Cylindrospermum sp.

J. Environ. Biol., 23 (2002), pp. 359-363

O.M. Lage, F. Sansonetty, J.-E. O'Connor, A.M. Parente

Flow cytometric analysis of chronic and acute toxicity of copper (II) on the marine dinoflagellate Amphidinium carterae

Cytometry, 44 (2001), pp. 226-235 
R. Muller, U. Schreiber, B.I. Escher, P. Quayle, S.M. Bengtson Nash, J.F. Mueller

Rapid exposure assessment of PSII herbicides in surface water using a novel chlorophyll a fluorescence imaging assay

Sci. Total Environ., 401 (2008), pp. 51-59

C. Nalewajko, M.M. Olaveson

Ecophysiological considerations in microalgal toxicity tests

P.G. Wells, K. Lee, C. Blaise (Eds.), Microscale Testing in Aquatic Toxicology: Advances, Techniques, and Practice, CRC, Boca Ratón, FL (1998), pp. 289-309

Y.W. Nancharaiah, M. Rajadurai, V.P. Venugopalan

Single cell level microalgal ecotoxicity assessment by confocal microscopy and digital image analysis Environ. Sci. Technol., 41 (2007), pp. 2617-2621

H. Nguyen-Ngoc, C. Durrieu, C. Tran-Minh

Synchronous-scan fluorescence of algal cells for toxicity assessment of heavy metals and herbicides

Ecotoxicol. Environ. Saf., 72 (2009), pp. 316-320

X. Nie, J. Gu, J. Lu, W. Pan, Y. Yang

Effects of norfloxacin and butylated hydroxyanisole on the freshwater microalgaScenedesmus obliquus Ecotoxicology, 18 (2009), pp. 677-684

M.G. Ormerod

Analysis of DNA. General methods

M.G. Ormerod (Ed.), Flow Cytometry. A Practical Approach, Oxford University Press, Oxford (1990), pp. $69-87$

H. Palmer, M. Ohta, M. Watanabe, T. Suzuki

Oxidative stress-induced cellular damage caused by UV and methylviologen in Euglena gracilis and its suppression with rutin

J. Photochem. Photobiol. B, 67 (2002), pp. 116-129

\section{A. Patras, V. Artenie}

The influence of gramoxone herbicide on the content of the photosynthetic pigments inZea mays Ananele Stiintifice ale Universitatii "Alexandru Ioan Cuza”, Sectiunea Genetica si Biologie Moleculara, VIII (2007), pp. 27-29

J.L. Pereira, S.C. Antunes, B.B. Castro, C.R. Marques, A.M.M. Gonçalves, F. Gonçalves, R. Pereira Toxicity evaluation of three pesticides on non-target aquatic and soil organisms: commercial formulations versus active ingredient

Ecotoxicology, 18 (2009), pp. 455-463

R. Perl-Treves, A. Perl

Oxidative stress: an introduction 
D. Inzé, M. Van Montagu (Eds.), Oxidative Stress in Plants, Taylor \& Francis, London (2002), pp. 1-32

I. Pouneva

Evaluation of algal culture viability and physiological state by fluorescent microscopic methods

Bulg. J. Plant Physiol., 23 (1997), pp. 67-76

R. Prado, R. García, C. Rioboo, C. Herrero, J. Abalde, A. Cid

Comparison of the sensitivity of different toxicity test endpoints in a microalga exposed to the herbicide paraquat

Environ. Int., 35 (2008), pp. 240-247

R. Prado, R. García, C. Rioboo, C. Herrero, J. Abalde, A. Cid

Use of the comet assay to evaluate pesticide toxicity on non-target microalgae

A. Kocsis, H. Molnar (Eds.), Genotoxicity: Evaluation, Testing and Prediction, Nova Publishers, New York (2009), pp. 311-319

R. Prado, C. Rioboo, C. Herrero, A. Cid

The herbicide paraquat induces alterations in the elemental and biochemical composition of non-target microalgal species

Chemosphere, 76 (2009), pp. 1440-1444

H. Qian, W. Chen, L. Sun, Y. Jin, W. Liu, Z. Fu

Inhibitory effects of paraquat on photosynthesis and response to oxidative stress inChlorella vulgaris

Ecotoxicology, 18 (2009), pp. 537-543

C. Rioboo, R. Prado, C. Herrero, A. Cid

Population growth study of the rotifer Brachionus sp. fed with triazine-exposed microalgae

Aquat. Toxicol., 83 (2007), pp. 247-253

K. Sakthivel, T. Watanabe, H. Nakamoto

A small heat-shock protein confers stress tolerance and stabilizes thylakoid membrane proteins in cyanobacteria under oxidative stress

Arch. Microbiol., 191 (2009), pp. 319-328

H.M. Shapiro

Practical Flow Cytometry

(3rd ed.)Wiley-Liss Inc., New York (1995)

C. Sobrino, O. Montero, L.M. Lubián

UV-B radiation increases cell permeability and damages nitrogen incorporation mechanism in Nannochloropsis gaditana

Aquat. Sci., 66 (2004), pp. 421-429

Strickland and Parsons, 1972 


\section{J.D. Strickland, T.R. Parsons}

A Practical Handbook of Seawater Analysis

Fisheries Research Board of Canada, Otawa (1972) Bulletin 167

\section{Z.E. Suntres}

Role of antioxidants in paraquat toxicity

Toxicology, 180 (2002), pp. 65-77

S. Ünyayar, Y. Keles, F.Ö. Cekic

The antioxidative response of two tomato species with different drought tolerances as a result of drought and cadmium stress combinations

Plant Soil Environ., 51 (2005), pp. 57-64

C.I. Vamanu, M.R. Cimpan, P.J. Hol, S. Sornes, S.A. Lie, N.R. Gjerdet

Induction of cell death by $\mathrm{TiO} 2$ nanoparticles: studies on a human monoblastoid cell line

Toxicol. In Vitro, 22 (2008), pp. 1689-1696

A.P. van Wezel, P. van Vlaardingen

Environmental risk limits for antifouling substances

Aquat. Toxicol., 66 (2004), pp. 427-444

M.J.W. Veldhuis, G.W. Kraay, K.R. Timmermans

Cell death in phytoplankton: correlation between changes in membrane permeability, photosynthetic activity, pigmentation and growth

Eur. J. Phycol., 36 (2001), pp. 167-177

N. Warren, I.J. Allan, J.E. Carter, W.A. House, A. Parker

Pesticides and other microorganic contaminants in freshwater sedimentary environments-a review

Appl. Geochem., 18 (2003), pp. 159-194

P.K. Wong

Effects of 2,4-D, glyphosate and paraquat on growth, photosynthesis and chlorophyll-asynthesis of Scenedesmus quadricauda Berb 614

Chemosphere, 41 (2000), pp. 177-182

B.P. $\mathrm{Yu}$

Cellular defenses against damage from reactive oxygen species

Physiol. Rev., 74 (1994), pp. 139-162

Corresponding author. Tel.: +34 981167 000; fax: +34 981167065 .

Copyright @ 2010 Elsevier B.V. All rights reserved. 